\title{
VANADIAN-CHROMIAN TOURMALINE AND VANADIAN MUSCOVITE IN CONTACT-METAMORPHOSED CARBONACEOUS ROCKS, PRIMORYE, RUSSIA
}

\author{
VALENTINE T. KAZACHENKO, LIDIA A. BUTSIK, VALERY I. SAPIN, \\ IGOR V. KITAEV, NICHOLAS N. BARINOV AND GENNADY A. NARNOV
}

Far East Geological Institute, Far East Science Branch, Russian Academy of Sciences, 690022 Vladivostok, Russia

\begin{abstract}
Vanadian-chromian tourmaline (as much as $4.06 \mathrm{wt} . \% \mathrm{~V}_{2} \mathrm{O}_{3}$ and $2.38 \% \mathrm{Cr}_{2} \mathrm{O}_{3}$ ) and vanadian muscovite (as much as $2.73 \%$ $\mathrm{V}_{2} \mathrm{O}_{3}$ ) occur in contact-metamorphosed carbonaceous metasediments of the Pribrezhnaya anticlinal zone in Primorye, Russia. Crystals are compositionally zoned, showing depletion in $\mathrm{V}$ and $\mathrm{Cr}$, and enrichment in $\mathrm{Al}, \mathrm{Mg}$ and $\mathrm{Fe}$, from core to rim. Zoning is attributed to progressive decrease of $\mathrm{V}$ and $\mathrm{Cr}$ contents in the host rock during the course of crystal growth. $\mathrm{Cr}$ and $\mathrm{V}$ are incorporated according to the schemes: $\mathrm{Cr}^{3+} \leftrightarrow \mathrm{Al}^{3+}$ and $\mathrm{V}^{3+} \leftrightarrow\left(\mathrm{Mg}^{2+}, \mathrm{Fe}^{2+}, \mathrm{Mn}^{2+}\right)$. The charge increase that results from the latter exchange is considered to be compensated by the concomitant substitution of ${ }^{\mathrm{rV}} \mathrm{Al}$ for $\mathrm{Si}$ and by the appearance of vacancies in the $X$ site. The associated vanadian muscovite contains minor amounts of $\mathrm{Mg}, \mathrm{Fe}, \mathrm{Ti}$ and Na. An empirical formula calculated from results of an electron-microprobe analysis is $\left(\mathrm{K}_{1.94} \mathrm{Na}_{0.09}\right)_{\Sigma 2.03}\left(\mathrm{Al}_{3.34} \mathrm{~V}_{0.29} \mathrm{Mg}_{0.26} \mathrm{Ti}_{0.05} \mathrm{Fe}_{0.04}\right)_{\Sigma 3.98}$ $\left(\mathrm{Si}_{6.27} \mathrm{Al}_{1.73}\right)_{\Sigma 8.00} \mathrm{O}_{22}(\mathrm{OH})_{2}$. Both minerals are products of contact metamorphism of $\mathrm{V}$-Cr-bearing carbonaceous rocks.

Keywords: vanadian-chromian tourmaline, vanadian $2 M_{1}$ muscovite, electron-microprobe analysis, carbonaceous rocks, contact metamorphism, Primorye, Russia.

\section{SOMMAIRE}

Nous avons trouvé une tourmaline vanadifère et chromifère (jusqu'à $4.06 \%$ de $\mathrm{V}_{2} \mathrm{O}_{3}$ et $2.38 \%$ de $\mathrm{Cr}_{2} \mathrm{O}_{3}$, en poids) et une muscovite vanadifère (jusqu' $2.73 \% \mathrm{~V}_{2} \mathrm{O}_{3}$ ) dans des métasédiments carbonacés d' une auréole de contact dans la zone anticlinale de Primorye, en Russie. Les cristaux montrent une zonation chimique, avec appauvrissement progressif en $\mathrm{V}$ et $\mathrm{Cr}$, et enrichissement en $\mathrm{Al}, \mathrm{Mg}$ et $\mathrm{Fe}$, du coeur vers la bordure. Nous attribuons cette zonation à la pénurie progressive en $\mathrm{V}$ et $\mathrm{Cr}$ dans la roche hôte pendant la croissance des cristaux. Le $\mathrm{Cr}$ et le $\mathrm{V}$ seraient incorporés dans la structure de la tourmaline selon les couples $\mathrm{Cr}^{3+} \leftrightarrow \mathrm{Al}^{3+}$ et $\mathrm{V}^{3+} \leftrightarrow\left(\mathrm{Mg}^{2+}, \mathrm{Fe}^{2+}, \mathrm{Mn}^{2+}\right)$. L'augmentation des charges positives impliquée par le deuxième couple serait compensée par le remplacement de Si par ${ }^{I V} \mathrm{Al}$ et par la présence de lacunes dans la position $X$. La muscovite vanadifère associée contient de faibles concentrations de $\mathrm{Mg}, \mathrm{Fe}$, Ti et $\mathrm{Na}$. Une formule empirique, calculée à partir de données obtenues à la microsonde électronique, serait $\left(\mathrm{K}_{1.94} \mathrm{Na}_{0.09}\right)_{\Sigma 2.03}\left(\mathrm{Al}_{3.34} \mathrm{~V}_{0.29} \mathrm{Mg}_{0.26} \mathrm{Ti}_{0.05} \mathrm{Fe}_{0.04}\right)_{\Sigma 3.98}\left(\mathrm{Si}_{6.27} \mathrm{Al}_{1.73}\right)_{\Sigma 8.00} \mathrm{O}_{22}(\mathrm{OH})_{2}$. Les deux minéraux sont le produit du métamorphisme de contact de roches carbonacées porteuses de chrome et de vanadium.
\end{abstract}

(Traduit par la Rédaction)

Mots-clés: tourmaline vanadifêre et chromifère, muscovite $2 M_{1}$ vanadifère, données à la microsonde électronique, roches carbonacées, métamorphisme de contact, Primorye, Russie.

\section{INTRODUCTION}

Only a few examples of tourmaline with significant contents of vanadium $\left(>1.0\right.$ wt. $\left.\% \quad \mathrm{~V}_{2} \mathrm{O}_{3}\right)$ have been recorded in the literature. Badalov (1951) reported the occurrence of $\mathrm{V}$-rich tourmaline $\left(5.76 \% \mathrm{~V}_{2} \mathrm{O}_{3}\right)$ in black quartz-graphite hornfels in contact with a quartz vein from Uzbekistan. Vanadiferous tourmaline $\left(1.5 \% \mathrm{~V}_{2} \mathrm{O}_{3}\right)$ from Tanga Province, Tanzania, was described by Basset (1956); it occurs in gneiss associated with dolomite and ultrabasic rocks as well as granulite-facies metasediments. Snetsinger (1966) described a Cr-bearing $\left(0.89 \% \quad \mathrm{Cr}_{2} \mathrm{O}_{3}\right)$ and exceedingly $\mathrm{V}$-rich $(7.45 \%$ $\mathrm{V}_{2} \mathrm{O}_{3}, 0.58 \% \mathrm{~V}_{2} \mathrm{O}_{4}$ ) tourmaline from a quartz-graphite schist, Mariposa County, California. Electron-microprobe analysis of an additional specimen from this locality gave $1.48 \% \mathrm{Cr}_{2} \mathrm{O}_{3}$ and $8.52 \% \quad \mathrm{~V}_{2} \mathrm{O}_{3}$ (Foit \& Rosenberg 1979). Schmetzer et al. (1979) gave chemical data on Cr-bearing, V-rich tourmaline $\left(0.55 \% \mathrm{Cr}_{2} \mathrm{O}_{3}\right.$, $4.03 \% \mathrm{~V}_{2} \mathrm{O}_{3}$ ) from the Kwal district, Kenya. Nickel \& Grey (1986) reported the occurrence of a vanadian schorl $\left(2.7 \% \mathrm{~V}_{2} \mathrm{O}_{3}\right)$ within the gold-bearing lodes from Kalgoorlie, Western Australia. Pan \& Fleet (1992) have recently noted that tourmaline from the Hemlo gold deposit, Ontario, contains $1.48 \% \mathrm{~V}_{2} \mathrm{O}_{3}$. High-chromium tourmaline found in Finland $\left(9.6 \% \mathrm{Cr}_{2} \mathrm{O}_{3}\right.$ ) (Peltola et al. 1968 ) and Swat, western Pakistan (Alpurai: $8.5 \% \mathrm{Cr}_{2} \mathrm{O}_{3}$, Mingora: $8.78 \% \mathrm{Cr}_{2} \mathrm{O}_{3}$ ) (Jan et al. 1972, Hammarstrom 
1989) contain up to $1.0 \% \mathrm{~V}_{2} \mathrm{O}_{3}$. Published data on chromian dravite and chromian varieties of tourmaline from world-wide locations have been compiled mainly by Dunn (1977), Nuber \& Schmetzer (1979), Rumyantseva (1983) and King \& Kerrich (1989).

Relatively few examples of vanadiferous $2 M_{1}$ muscovite have been reported in the literature. A V-bearing, Ba-rich muscovite $\left(1.48 \% \mathrm{~V}_{2} \mathrm{O}_{3}, 1.95 \% \mathrm{~V}_{2} \mathrm{O}_{4}, 2.39 \%\right.$ $\mathrm{BaO}$ ), coexisting with the $\mathrm{V}-\mathrm{Cr}$-bearing tourmaline mentioned above, was reported by Snetsinger (1966). $\mathrm{V}$-Cr-bearing muscovite $\left(5.09 \% \mathrm{~V}_{2} \mathrm{O}_{3}, 0.8 \% \mathrm{Cr}_{2} \mathrm{O}_{3}\right)$ from the Janggun mine area, Republic of Korea, was described by Imai et al. (1980). It occurs in close association with quartz, vanadian tourmaline (about $3 \%$ $\mathrm{V}_{2} \mathrm{O}_{3}$ ) and graphite. These minerals are regarded by the authors as being the products of regional metamorphism of orthoquartzite. Recent investigations include the description of $\mathrm{Cr}$-V-bearing micas from southern Karelia, Russia, by Rumyantseva et al. (1984). Amongst the other micas composing metasomatic veins, nests and solid masses in dolomites, slates and diabases, muscovite $\left(3.0 \% \mathrm{Cr}_{2} \mathrm{O}_{3}, 10.4 \% \mathrm{~V}_{2} \mathrm{O}_{3}\right)$ is present.

This paper documents the occurrence of chromian $V$-rich tourmaline and vanadiferous muscovite found in contact-metamorphosed carbonaceous rocks of the Pribrezhnaya anticlinal zone in Primorye, in the Far-Eastern region of Russia.

\section{Geological SetTing}

Carbonaceous rocks are a minor but integral part of the basement of the East Sikhote - Alin volcanogenic belt. The basement rocks, exposed between two Late Cretaceous granitic massifs, comprise Late Paleozoic, Triassic and Jurassic marine deposits such as arkosic sandstones, siltstones, cherts, siliceous shales and reef limestones (Fig. 1). Amongst these deposits occur horizons of basalt, metamorphosed and recrystallized manganese ores, iron ores and $\mathrm{Mn}$ - and Fe-rich calc-silicate rocks.

\section{The Carbonaceous Rocks}

Carbonaceous rocks constitute a bed about $2 \mathrm{~m}$ thick in Triassic cherts. They were originally siltstones and pelites (Table 1) rich in organic matter before contact metamorphism due to the intrusion of granitic magma.

Under the polarizing microscope, the low-metamorphic-grade carbonaceous rocks display a wavy texture, which is most distinctly reflected in the arrangement of the carbonaceous material. Rare fragments of feldspar and cement were variously replaced by muscovite. Segregations of rutile and newly formed albite and biotite are common. Xenotime and monazite also occur. The carbonaceous matter is present in cement in a finely dispersed state and as irregular fragments (phytoclasts?) up to $0.04 \mathrm{~mm}$ across.

More intensely metamorphosed carbonaceous rocks
TABLE 1. CARBON CONTENT* OF CARBONACEOUS ROCKS

\begin{tabular}{|c|c|c|c|}
\hline Sample & Rock type & $C_{\text {organic }}$ & $\mathrm{C}_{\text {carbonate }}$ \\
\hline SH-8634 & $\begin{array}{l}\text { Muscovite-andalusite- } \\
\text { cordierite slate }\end{array}$ & 3.13 wt. 8 & $0 \mathrm{wt}$. \\
\hline SAd -8648 & siltstone & 0.80 & 0.04 \\
\hline SH一Bด79A & sultstone & 2.80 & 0 \\
\hline$S H=86 B / N$ & Siltatone & 4.60 & 0 \\
\hline
\end{tabular}

- Determined by gasometric analysis following the procedure indicated by Kolpack Bell (1988), on the apperatus descorlbed by Kitaev \& INkht (1971). Analyst: L. Yu. Kurbatova.

are represented by muscovite - andalusite - cordierite slates. They consist of cordierite and andalusite porphyroblasts extensively replaced by muscovite and a matrix of clayey and carbonaceous particles and grains of quartz; rare porphyroblasts of muscovite also' are present. The carbonaceous substance was examined under a TESLA BS-540 transmission electron microscope at $120 \mathrm{kV}$. An electron-diffraction pattern obtained proved to be identical with that of graphite.

Quantitative spectrographic analyses of carbonaceous rocks revealed a wide spectrum of trace elements: $\mathrm{V}(200$ to $500 \mathrm{ppm}), \mathrm{Ba}(\leq 600), \mathrm{Sr}(\leq 300), \mathrm{Zn}$ and $\mathrm{Zr}$ $(\leq 200), \mathrm{Cr}(60$ to 160$), \mathrm{Cu}, \mathrm{Pb}$ and $\mathrm{Ni}(\leq 100)$, Mo $(\leq 80), \mathrm{Co}(\leq 46), \mathrm{Ga}(\leq 40), \mathrm{Y}$ and $\mathrm{La}(\leq 30), \mathrm{Nb}(\leq 20)$, $\mathrm{Ag}(\leq 9)$ and $\mathrm{Sn}(\leq 5)$. Another feature is the high content of $\mathrm{Ti}$, which exceeds $1 \mathrm{wt} \% \mathrm{TiO}_{2}$. The samples were analyzed by a standard emission spectrographic technique (Rusanov 1978) using a DFS-8 apparatus.

\section{V-Cr-BEARING TOURMALINE}

The $\mathrm{V}-\mathrm{Cr}$-bearing tourmaline is found in the lowmetamorphic-grade carbonaceous siltstone. The mineral forms minute subhedral to euhedral grains (Fig. 2), which are sparsely scattered throughout the rock cement and do not appear to exceed $2 \mathrm{vol} . \%$. The largest crystals (up to $0.4 \mathrm{~mm}$ in length) are confined mainly to loci of graphite masses occurring in the most intensely recrystallized matrix. In transmitted light, the tourmaline is greenish brown, with $\mathrm{N}_{\varepsilon}=$ pale green and $\mathrm{N}_{\omega}=$ brown. It was not possible to isolate optically uniform fragments of the mineral owing to the minute size of the grains. Only approximate indices of refraction and cell parameters were therefore obtained, using the crystals analyzed by electron microprobe. The indices of refraction $\varepsilon$ and $\omega$ of the tourmaline are 1.633(2) and 1.670(2), respectively. X-ray powder-diffraction studies were done in a 57.3-mm-diameter Debye-Scherrer camera using $\mathrm{Fe} K \alpha, \beta$ radiation. Indexing of the powder pattern and computation of the cell parameters were done using the CRYST program (Nakhmanson \& Antoshulsky 1985). 


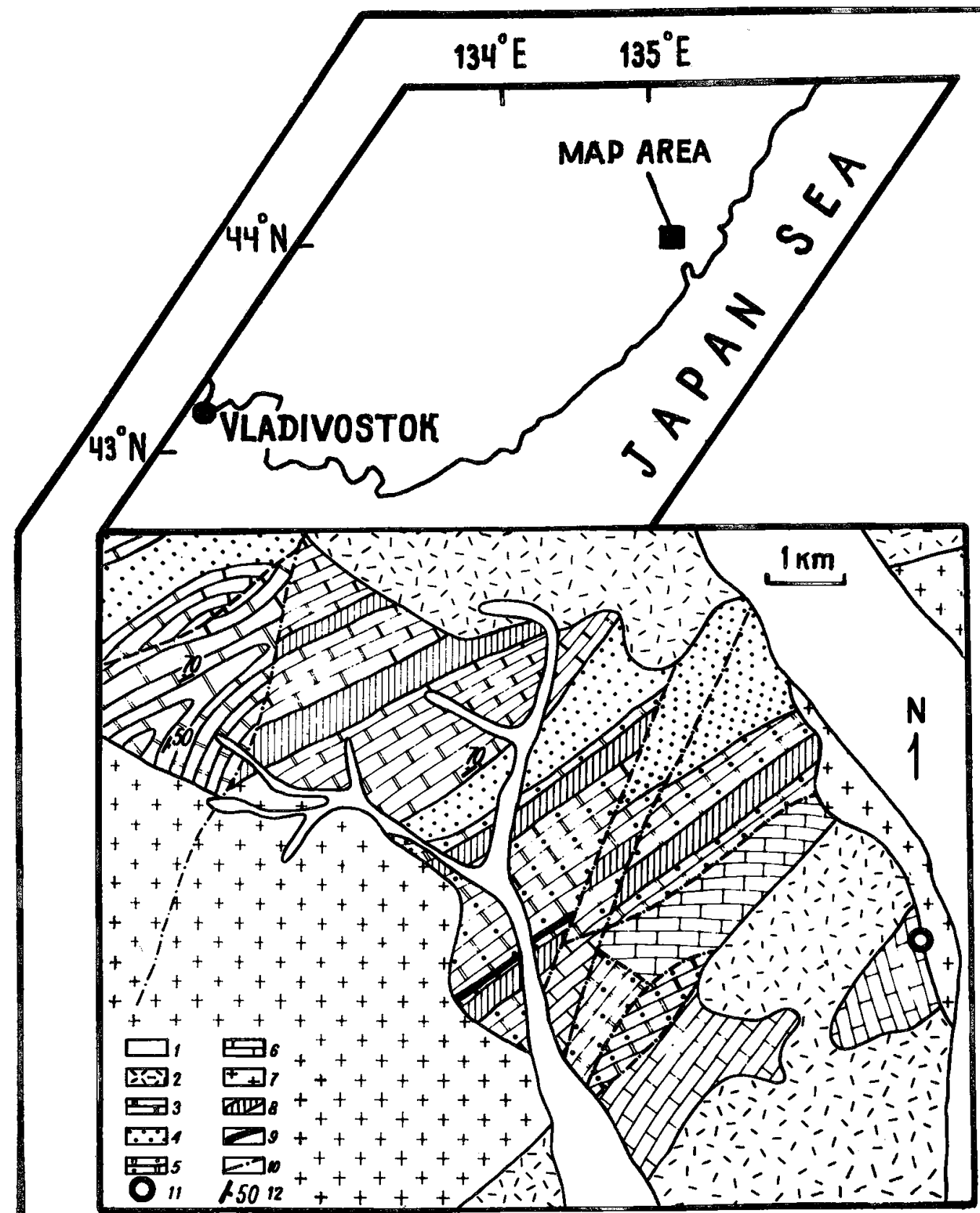

FIG. 1. Location and geological map of the study area, situated within the Primorye territory, Russia. Legend: 1 Quaternary sediments, 2 volcanogenic formations of the East Sikhote - Alin volcanogenic belt, 3 Jurassic terrigenous siliceous deposits, 4, 5 Triassic sandstones (4) and terrigenous siliceous deposits (5), 6 Carboniferous to Permian terrigenous siliceous deposits, 7 Late Cretaceous granites, 8 beds of essentially siliceous deposits containing layers and stockwork-like zones of iron-manganese mineralization, 9 carbonaceous siltstones, 10 faults, 11 Belogorskoye field of magnetite skarns, 12 strike and dip of bedding. 


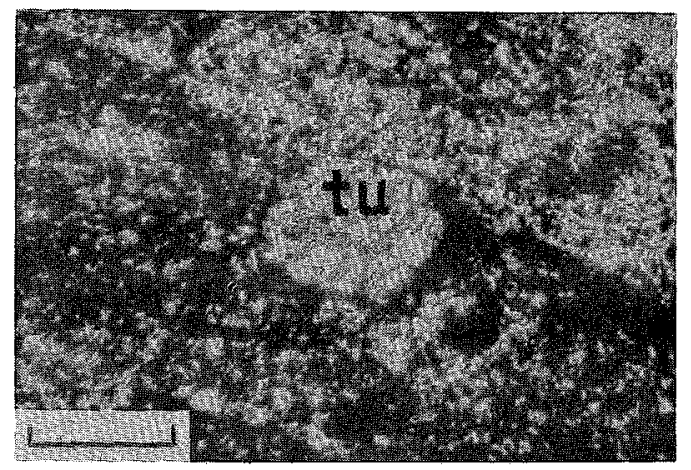

FIG. 2. Subhedral grain of tourmaline (tu) in carbonaceous siltstone. Scale bar is $40 \mu \mathrm{m}$. Plane-polarized light. Specimen SH-8679.

Cell dimensions of the tourmaline are: $a$ 15.915(2), and c 7.187(3) $\AA$.

Owing to the limited amount of material available, partial analyses were carried out for two individual grains of tourmaline in a polished section with a scanning electron microscope equipped with energydispersion spectrometers (Figs. 3A, B). Analytical data for the crystal (Fig. 3A) free of impurities and only slightly fractured are given in Table 2. Analyses were performed with a JXA-5A (JEOL) electron microprobe not modified for the detection of low-atomic-number elements ( $Z$ less than 11 ); concentrations of $B$ and $F$ were therefore not determined. The tourmaline is a chromian and V-rich variety of dravite. In other constituents, it appears to resemble normal dravite closely. The composition of the mineral is heterogeneous. Figure 4 shows






direction of scan

FiG. 3. Photomicrographs of two tourmaline crystals, I (A,C,E) and II (B,D,F). Specimen SH-8679. A and B. Secondary electron images. Crystals are surrounded by rock matrix. Numbers at dots $(1-4)$ on $A$ refer to spots analyzed by electron probe and can be used to identify specific compositions in Table 2. C and D. VK $\alpha$ X-ray images. $\mathrm{E}$ and $\mathrm{F}$. $\mathrm{Cr} K \alpha \mathrm{X}$-ray images. Scale bar is $40 \mu \mathrm{m}$; it applies to all photomicrographs. Note: white stains on $\mathrm{F}$ (left) are due to contamination. G. Simplified line-scan profiles showing the variation in intensities of characteristic $K \alpha \mathrm{X}$ rays along the line drawn on $\mathrm{A}$ (cps: counts per second). 

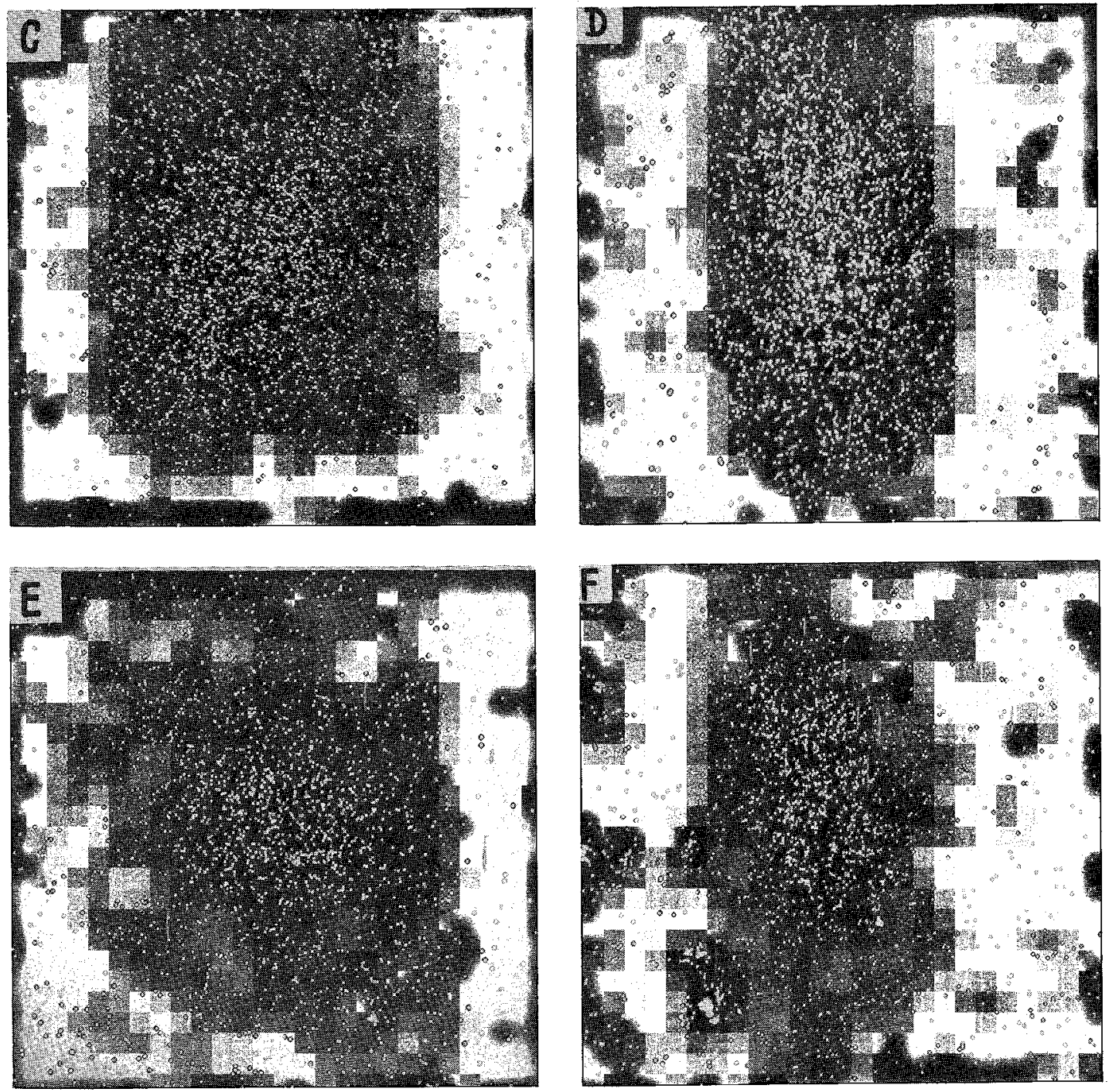

that an increase in $\mathrm{V}$ content is accompanied by an increase in $\mathrm{Cr}$ content and decreases in $\mathrm{Al}$ and total $\mathrm{Mg}$, $\mathrm{Fe}$ and $\mathrm{Mn}$ contents. The muscovite that coexists with the tourmaline contains no $\mathrm{Cr}$ or $\mathrm{V}$ (Table 2).

$\mathrm{X}$-ray emission images $\mathrm{VK} \alpha$ (Figs. 3C, D) and $\mathrm{Cr} K \alpha$ (Figs. 3E, F) and scanning profiles for $\mathrm{Al} K \alpha, \mathrm{MgK \alpha}$, $\mathrm{V} K \alpha$ and $\mathrm{Cr} K \alpha$ (Fig. 3G) illustrate the compositional zonation of the tourmaline crystals. The zonal distribution of elements is metamorphic in origin; there is a gradual change in composition from the core to the rim (Fig. 3G). The core is enriched in $\mathrm{V}$ and $\mathrm{Cr}$ (Figs. 3C-G) and depleted in $\mathrm{Al}$ and $\mathrm{Mg}$ (Fig. 3G). The contents of $\mathrm{Al}$ and $\mathrm{Cr}$ do not vary appreciably in the core and rim, but compositional gradients are steep between the two zones. Relatively steady variations from core to rim are

observed for $\mathrm{Mg}$ and $\mathrm{V}$. Such peculiarities in the behavior of $\mathrm{Al}$ and $\mathrm{Cr}$ on the one hand and of $\mathrm{Mg}$ and $\mathrm{V}$ on the other can be explained by isomorphous replacement of $\mathrm{Al}$ by $\mathrm{Cr}$ as well as of $\mathrm{Mg}$ by $\mathrm{V}$, and can provide some indication of the preference of these element couples for occupancy of different octahedral sites. The distribution of $\mathrm{Ca}$ and $\mathrm{Ti}$ within the crystal is uniform (Fig. 3G).

In order to determine the site of $\mathrm{Ca}$ in the calculation of the structural formula of tourmaline (Table 3 ), results of about 120 chemical analyses were recalculated to an anhydrous formula containing 24.5 atoms of oxygen. The analytical data were selected from the compilations of Dunn (1977), Dolomanova et al. (1978), Kuzmin et al. (1979) and Kornetova (1981). 
TABLE 2. CHEMICAL COMPOSITION OF TOURMALINE AND MUSCOVITE FROM PRIMORYE, RUSSIA

\begin{tabular}{|c|c|c|c|c|c|c|c|c|c|c|c|c|}
\hline No. of spots" & 1 & 2 & 3 & 4 & 5 & 6 & 7 & 8 & 9 & 10 & 11 & 12 \\
\hline $\mathrm{SiO}_{2}$ wt. & 35.50 & 37.28 & 36.33 & 36.04 & 35.79 & 36.11 & 35.88 & 35.67 & 36.09 & 35.86 & 45.61 & 46.98 \\
\hline $\mathrm{THO}_{2}$ & -0.81 & 0.92 & 0.59 & 0.51 & 0.65 & 0.60 & 0.61 & 0.70 & 0.54 & 0.28 & 0.40 & 0.47 \\
\hline $\mathrm{Al}_{2} \mathrm{O}_{3}$ & 30.59 & 32.52 & 32.24 & 32.41 & 31.89 & 32.41 & 30.89 & 30.99 & 32.57 & 30.74 & 33.32 & 32.24 \\
\hline $\mathrm{Cr}_{2} \mathrm{O}_{3}$ & 2.38 & 0.00 & 0.65 & 0.59 & 1.07 & 0.86 & 1.09 & 2.11 & 0.69 & 1.87 & 0.00 & 0.00 \\
\hline $\mathrm{v}_{2} \mathrm{O}_{3}$ & 4.08 & 0.00 & 2.67 & 1.62 & 2.37 & 1.77 & 2.51 & 3.81 & 1.84 & 4.00 & 0.00 & 2.73 \\
\hline $\mathrm{FeO}$ & 1.41 & 3.22 & 1.61 & 1.55 & 1.56 & 1.51 & 1.52 & 1.42 & 1.57 & 1.48 & 1.18 & 0.34 \\
\hline MnO & 0.07 & 0.10 & 0.08 & 0.04 & 0.04 & 0.06 & 0.06 & 0.08 & 0.08 & 0.00 & 0.00 & 0.00 \\
\hline MgO & 8.12 & 9.02 & 8.07 & 8.87 & 8.99 & 8.87 & 8.67 & 8.09 & 9.09 & 8.36 & 3.73 & 1.28 \\
\hline $\mathrm{CaO}$ & 1.29 & 1.16 & 0.84 & 0.97 & 1.46 & 1.37 & 1.36 & 1.31 & 1.34 & 1.27 & 0.00 & 0.00 \\
\hline $\mathrm{Na}_{2} \mathrm{O}$ & 2.07 & 2.31 & 2.15 & 2.29 & 1.94 & 2.07 & 2.00 & 2.06 & 2.09 & 1.83 & 0.00 & 0.34 \\
\hline $\mathrm{K}_{2} \mathrm{O}$ & 0.05 & 0.02 & 0.09 & 0.07 & 0.08 & 0.09 & 0.08 & 0.10 & 0.08 & 0.06 & 10.42 & 11.38 \\
\hline anhydrous tota & 186.15 & 86.55 & 85.30 & 84.98 & 85.84 & 85.72 & 84.67 & 86.34 & 85.96 & 85.80 & 94.66 & 95.77 \\
\hline
\end{tabular}

Determined by electron microprobe, model JXA-5A (JEOL). Accelerating voltage: $20 \mathrm{kV}$, specimen current: $4 \times 10^{-8} \mathrm{~A}$, beam diameter: $2 \mu \mathrm{m}$, measurement of X-ray intensities by fixed-time (10 s) method of counting. Standards used: sanidine $\left(\mathrm{Ab}_{30}\right)$ for $\mathrm{K}, \mathrm{Na}, \mathrm{Al}$ and $\mathrm{SI}$, ilmenite for $\mathrm{Ti}$, chromite for $\mathrm{Cr}$, synthetic $\mathrm{V}_{2} \mathrm{O}_{5}$ for $\mathrm{V}$, oltvine $\left(\mathrm{FO}_{7}\right)$ for $\mathrm{Fe}$, rhodonite for $\mathrm{Mn}$, diopstde for $\mathrm{Ca}$ and $\mathrm{Mg}$. Concentrations calculated and $\mathrm{ZAF}$ correction made using computer program of Afonin et al. (1971). Concentrations of B and $F$ were not sought. Arbitrary points chosen on the crystals: 1-10 tourmaline (SH-8679A), 11 and 12 muscovite (SH-8679A and SH-8634, respectively). "All iron expressed as FeO.

A notable proportion $(\approx 35 \%)$ of both the non-Cabearing tourmalines and the $\mathrm{Ca}$-bearing ones shows full occupancy of the $Y$ site. At the same time, we found that Ca occupancy of either $X$ or $Y$ positions is controlled by the sign $(+/-)$ of the resulting excess charge (hereafter termed $\mathrm{EXCH}$ ) arising from the incorporation of cations into tetrahedrally and octahedrally coordinated positions (Fig. 5). Compensation of positive EXCH leads to the appearance of vacancies in the $X$ site, and $\mathrm{Ca}$ either does not substitute into tourmaline or occupies only the $Y$ site. Negative $\mathrm{EXCH}$ is balanced by means of $\mathrm{Ca}$ accommodation in the $X$ site.

A few separate data-points situated as a rule near the origin (Fig. 5) show $\mathrm{Ca}$ in the $X$ site of tourmaline with positive EXCH values. This departure is most probably due to errors in the chemical analysis. The rest of the tourmaline compositions $(\approx 65 \%)$ are, as a rule, distinguished by a high positive value of $\mathrm{EXCH}$, and they have vacancies in both large cationic sites $(X$ and $Y$ ). From the data in Figure 6 , it follows that the replacement of divalent by trivalent cations is at first accompanied by an increase in the number of vacancies in the $X$ site. When the number of vacancies reaches some upper limit that is presumably controlled by P-T conditions during growth, further compensation of EXCH leads to the appearance of cation deficiencies in the $Y$ site. These deficiencies may explain the origin of vacancies according to the substitution $3 R^{2+} \leftrightarrow 2 R^{3+}+\square$. This scheme is in good agreement with the distribution of the different number of vacancies in the $X$ site within the field defined by lines I and V (Fig. 6). However, if the compensation for $\mathrm{EXCH}$ takes place in accordance with the dehydroxylation-type of substitution proposed by Foit \& Rosenberg (1977), then the deficiency of cations in the $Y$ site may be a result of an error due to the normalization of the chemical data on the basis of 24.5 atoms of oxygen. In this case, the trends on Figure 6 will have nearly the same slope as those corresponding to the scheme $3 R^{2+} \leftrightarrow 2 R^{3+}+\square$. Thus, Figure 6 does not allow determination of the actual type of cation substitution but may be used for geothermobarometry and for classification of tourmaline-group minerals.

Structural formulae of the $\mathrm{Cr}-\mathrm{V}$-bearing tourmaline (Table 3) calculated on the basis of 24.5 atoms of oxygen, and with due regard for the above-stated considerations, imply a partial substitution of $\mathrm{Si}$ by $\mathrm{Al}$. The presence of ${ }^{\mathrm{IV}} \mathrm{Al}$ is confirmed by the distinct splitting of the infrared-absorption band (Fig. 7), located at $780 \mathrm{~cm}^{-1}$, into two components at 783 and 764 $\mathrm{cm}^{-1}$ (Dolomanova et al. 1978). The infrared-absorption spectrum was obtained with a UR-20 spectrophotometer using a $300-\mathrm{mg} \mathrm{KBr}$ disk containing $1 \mathrm{mg}$ of tourmaline.

Complete cationic occupancy of $Y$ and $Z$ sites means that the substitution of $\mathrm{V}$ for divalent cations as well as $\mathrm{Cr}$ for $\mathrm{Al}$ has taken place in a 1:1 ratio. The cationic composition of $Y$ sites in tourmalines can be estimated from the infrared stretching bands located in the 3600$3400 \mathrm{~cm}^{-1}$ region and have been interpreted (Dolomanova et al. 1978, Gonzalez-Carreno et al. 1988) as being characteristic of $\mathrm{OH}$ interaction with $2 \mathrm{Al}^{3+}$ and $1 Y$ cation (Mg, Fe, Al, etc.).

In the IR absorption spectrum of the tourmaline examined (Fig. 7), the most intense component (3580 $\mathrm{cm}^{-1}$ ) corresponds to $\mathrm{Al}-\mathrm{Al}-\mathrm{Mg}$ associations and is shifted toward higher frequencies relative to the analogous band in dravite $\left(3568 \mathrm{~cm}^{-1}\right.$, according to GonzalezCarreno et al. 1988). The $3545 \mathrm{~cm}^{-1}$ band probably corresponds to Al-Al-V environments. The $3515 \mathrm{~cm}^{-1}$ has a weak intensity and a frequency similar to that of 


\section{V-BEARING Muscovite}

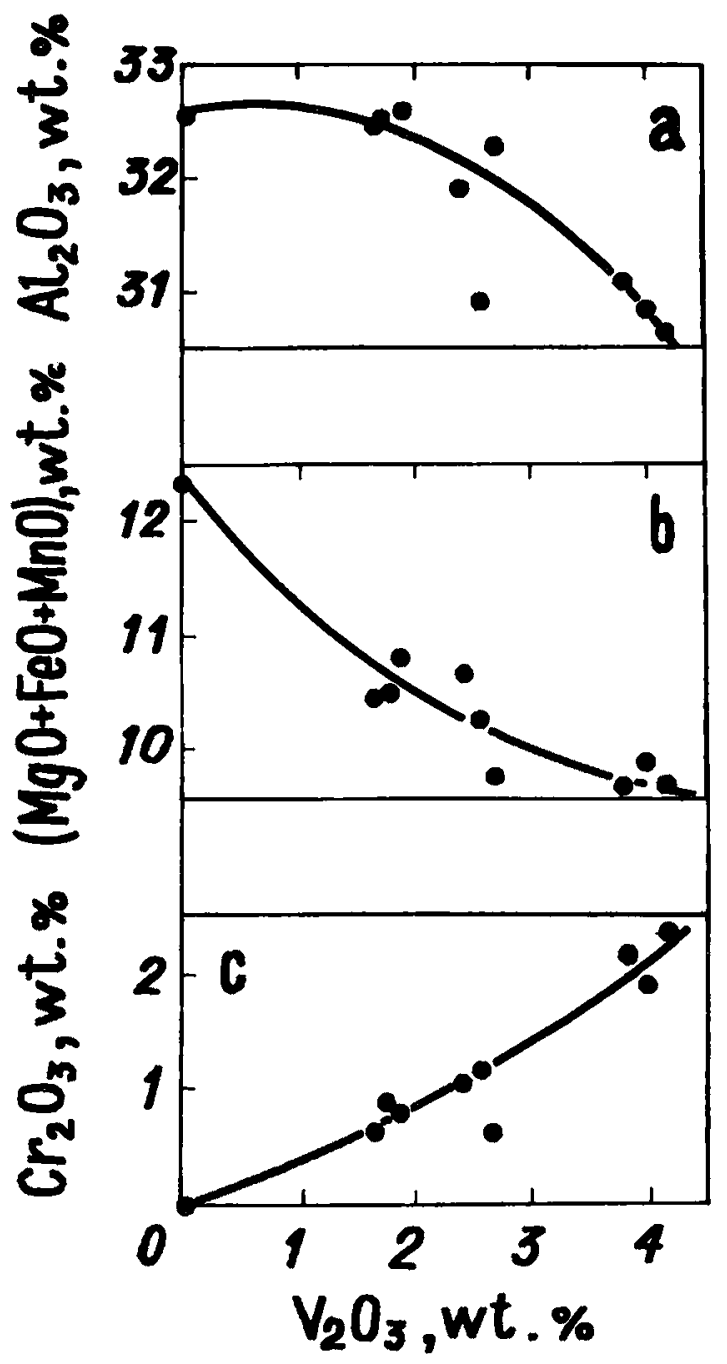

FIG. 4. Variation of $\mathrm{V}_{2} \mathrm{O}_{3}$ with a) $\mathrm{Al}_{2} \mathrm{O}_{3}$, b) $\mathrm{MgO}+\mathrm{FeO}$ (total iron) $+\mathrm{MnO}$, and c) $\mathrm{Cr}_{2} \mathrm{O}_{3}$ in tourmaline.

the band conforming to $\mathrm{Al}-\mathrm{Al}-\mathrm{Al}$ associations in the IR spectrum of dravite ( $3494 \mathrm{~cm}^{-1}$, according to GonzalezCarreno et al. 1988). However, careful analysis of interrelations between IR and chemical data (normalized to 24.5 atoms of oxygen) compiled by Dolomanova $e t$ al. (1978) has shown that the $3494 \mathrm{~cm}^{-1}$ band is typical only of the samples containing more than $0.35 \mathrm{Al}$ atom per formula unit in the $X$ site. In view of this reasoning, one ought to assume that the amount of $\mathrm{Al}^{3+}$ in the $Y$ site of the tourmaline analyzed is higher than that given in Table 3. Such an inference reflects the possible entry of a small amount of $\mathrm{V}^{3+}$ (Foit \& Rosenberg 1979) as well as $\mathrm{Mg}^{2+}$ (Nuber \& Schmetzer 1979) in the $Z$ site.
Vanadiferous muscovite is found in muscovite andalusite - cordierite slate. It forms porphyroblasts (2 to $3 \mathrm{~mm}$ across) which, in transmitted light, are colorless to faintly greenish and are not pleochroic.

The muscovite is enriched in $\mathrm{V}$ and contains some $\mathrm{Mg}, \mathrm{Fe}, \mathrm{Ti}$ and $\mathrm{Na}$ (Table 2). Sericite in the rock matrix appears to contain V, but far less than in the muscovite porphyroblasts. Results of electron-microprobe analyses of the vanadiferous mica (Table 2 ) recalculated on the basis of 22 atoms of oxygen (Table 3 ) correspond to the structural formula: $\left(\mathrm{K}_{1.94} \mathrm{Na}_{0.09}\right)_{22.03}\left(\mathrm{Al}_{3.34}\right.$ $\left.\mathrm{V}_{0.29} \mathrm{Mg}_{0.26} \mathrm{Ti}_{0.05} \mathrm{Fe}_{0.04}\right)_{23.98}\left(\mathrm{Si}_{6.27} \mathrm{Al}_{1.73}\right)_{28.00} \mathrm{O}_{22}$. V as well as $\mathrm{Mg}$ and $\mathrm{Fe}$ have replaced ${ }^{\mathrm{VI}} \mathrm{Al}$. This 1:1 substitution is charge-balanced by replacement of $\mathrm{Si}$ by ${ }^{\mathrm{IV}} \mathrm{Al}$.

The muscovite was observed by transmission electron microscopy in the same specimen as graphite (see above). An electron-diffraction pattern reveals that the vanadiferous mica is of the $2 M_{1}$ polytype modification, with cell parameters $a 5.19(1), b 9.05(2), c 20.23(4) \AA$, $\beta$ 95.0(5) ${ }^{\circ}$.

\section{Discussion}

$\mathrm{V}-\mathrm{Cr}$-bearing tourmaline and $\mathrm{V}$-bearing muscovite are products of contact metamorphism of carbonaceous rocks. Prerequisites for their appearance were the initial enrichment of sediments in $\mathrm{Cr}$ and $\mathrm{V}$ and a reducing environment due to a high content of organic carbon.

Concentrations of $\mathrm{V}, \mathrm{Cu}, \mathrm{Ni}, \mathrm{Mo}, \mathrm{Ag}$ and other elements are typical of natural organic compounds (Manskaya \& Drozdova 1964). Originally, the major portion of these elements may have been connected with the organic matter of the carbonaceous rocks described. A substantial role of basic material in the detrital component seems to be a cause of high concentration of $\mathrm{Cr}$ and $\mathrm{Ti}$ in the rocks.

Chemical zoning in tourmaline crystals is apparently due to progressive depletion of $\mathrm{V}$ and $\mathrm{Cr}$ during the course of crystal growth.

\section{ACKNOWLEDGEMENTS}

The authors thank Drs. Robert F. Martin and Eugene E. Foord for helpful comments, editorial scrutiny, assistance with English usage and clarification of the text of several versions of the manuscript, as well as their support and encouragement. Constructive criticism and many incisive comments on an earlier draft of the manuscript, including language correction by two anonymous referees, are greatly appreciated. Our thanks also to T.N. Samokish for typing of the manuscript, M.I. Kalacheva for drafting the figures, and E.B. Oleinik for word processing. 


\begin{tabular}{|c|c|c|c|c|c|c|c|c|c|c|c|c|}
\hline & 1 & 2 & 3 & 4 & 5 & B & 7 & 8 & 9 & 10 & 11 & 12 \\
\hline \multirow{3}{*}{${ }_{[\mathbf{V}}^{S}$} & 5.78 & 5.96 & 5.89 & 5.86 & 5.80 & 5.83 & 5.89 & 5.79 & 5.81 & 5.84 & 6.12 & 6.27 \\
\hline & 0.13 & 0.04 & 0.11 & 0.14 & 0.20 & 0.17 & 0.11 & 0.21 & $\underline{0.19}$ & $\underline{0.16}$ & $\underline{1.88}$ & 1.73 \\
\hline & $\overrightarrow{6.00}$ & 6.00 & 6.00 & 6.00 & 6.00 & 6.00 & 6.00 & 6.00 & 6.00 & 6.00 & 8.00 & 8.00 \\
\hline $\mathrm{v}_{\mathbf{A l}}$ & 5.65 & 6.00 & $\mathbf{5 . 9 1}$ & 5.92 & 5.86 & 5.89 & 5.86 & 5.72 & 5.90 & 5.74 & & \\
\hline $\mathrm{Cr}$ & 0.31 & 0.00 & 0.09 & 0.08 & 0.14 & 0.11 & 0.14 & 0.27 & 0.10 & 0.24 & & \\
\hline \multirow[t]{2}{*}{$v$} & $\underline{0.04}$ & $\underline{0.00}$ & & & & & & & & & & \\
\hline & 6.00 & 6.00 & 6.00 & 6.00 & 6.00 & 6.00 & 8.00 & 6.00 & 6.00 & 6.00 & & \\
\hline $\mathrm{Mg}_{\mathrm{g}}$ & 1.97 & 2.15 & 1.95 & 2.15 & 2.17 & 2.14 & 2.12 & 1.98 & 2.18 & 2.03 & 0.75 & 0.26 \\
\hline $\mathrm{Fe}$ & 0.18 & 0.43 & 0.22 & 0.21 & 0.21 & 0.21 & 0.21 & 0.19 & 0.21 & 0.20 & 0.13 & 0.04 \\
\hline Mn & 0.01 & 0.01 & 0.01 & & & 0.01 & 0.01 & 0.01 & 0.01 & 0.00 & & \\
\hline $\mathrm{Ca}$ & 0.22 & 0.20 & 0.14 & 0.17 & 0.25 & 0.24 & 0.24 & 0.23 & 0.23 & 0.22 & & \\
\hline $\mathrm{V}_{\mathrm{Al}}$ & & 0.10 & 0.15 & 0.15 & 0.03 & 0.11 & & & 0.10 & & 3.40 & 3.34 \\
\hline v & 0.49 & 0.00 & 0.35 & 0.22 & 0.30 & 0.23 & 0.34 & 0.48 & 0.24 & 0.51 & 0.00 & 0.29 \\
\hline \multirow[t]{2}{*}{$\mathbf{T I}$} & $\underline{0.08}$ & $\underline{0.11}$ & 0.08 & $\underline{0.06}$ & 0.08 & 0.08 & $\underline{0.08}$ & 0.09 & 0.07 & $\underline{0.03}$ & $\underline{0.04}$ & 0.05 \\
\hline & 2.98 & 3.00 & 2.90 & 2.88 & 3.04 & 3.02 & 3.00 & 2.96 & 3.04 & 2.99 & 4.32 & 3.88 \\
\hline $\mathrm{Na}$ & 0.65 & 0.72 & 0.68 & 0.72 & 0.81 & 0.65 & 0.63 & 0.65 & 0.65 & 0.61 & 0.00 & 0.09 \\
\hline \multirow[t]{2}{*}{$\mathbf{K}$} & 0.01 & - & $\underline{0.02}$ & $\underline{0.01}$ & $\underline{0.02}$ & $\underline{0.02}$ & $\underline{0.02}$ & $\underline{0.02}$ & $\underline{0.02}$ & $\underline{0.01}$ & 1.78 & 1.94 \\
\hline & $\overrightarrow{0.68}$ & 0.72 & 0.70 & $\overline{0.73}$ & $\overline{0.63}$ & $\overline{0.67}$ & $\overline{0.65}$ & 0.67 & 0.67 & 0.62 & 1.78 & 2.03 \\
\hline
\end{tabular}

Calculated on the basis of 24.5 atoms of oxygen for tourmaline (1-10) and 22 atoms of oxygen for muscovite

FIG. 5. Relationship between Ca (per formula unit) in $X$ site in tourmaline and value of positive or negative excess charge (EXCH), derived from the expression $\left(R_{Y}^{3+}+2 \mathrm{Ti}^{4+}\right)-\left(\mathrm{Li}^{+}+\right.$ $\left.\mathrm{Mg}^{2+}+{ }^{\mathrm{IV}} \mathrm{Al}^{3+}\right) \cdot X_{\square}$ is the number of vacancies in the $X$ site. Multiple points are not indicated. See text for details.

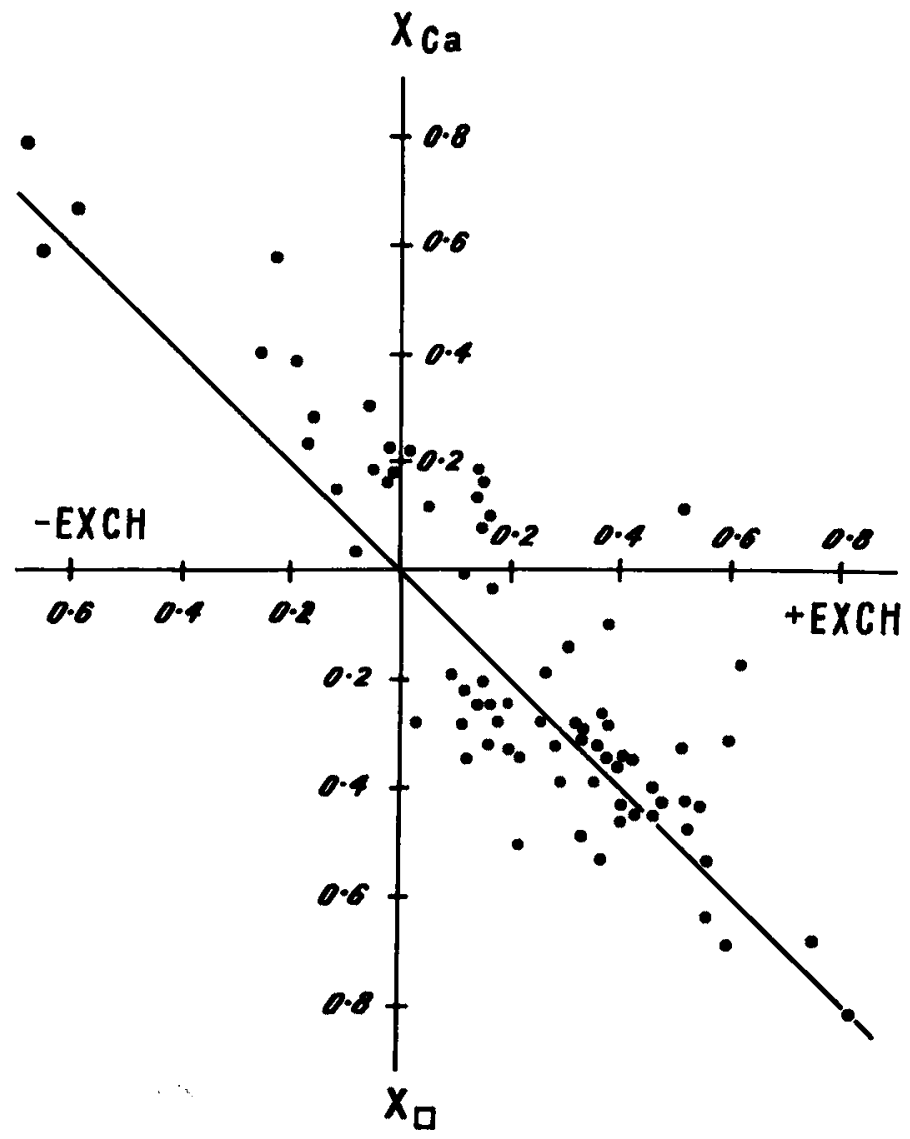




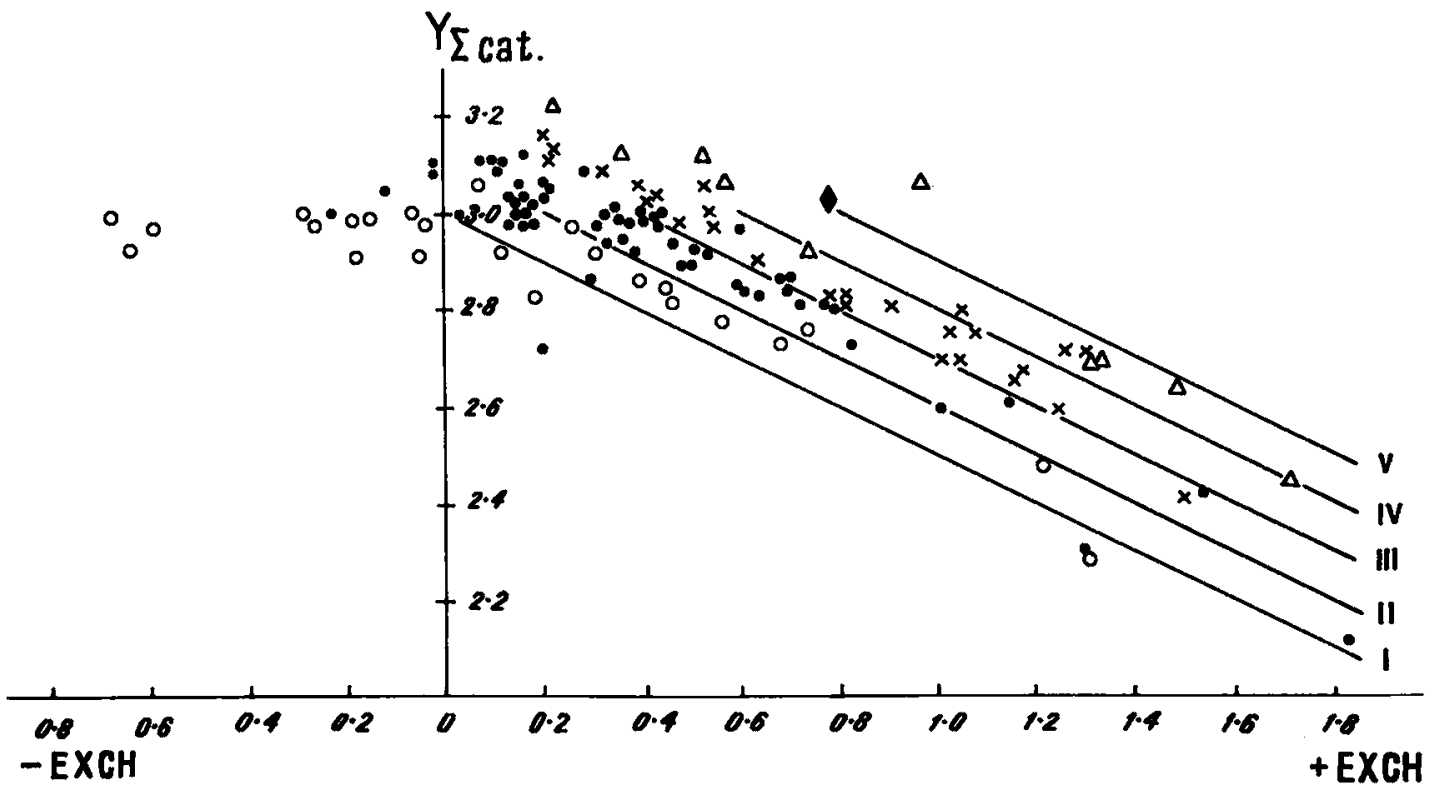

FIG. 6. Relationship between sum of $Y$ cations in tourmaline (per formula unit) and value of positive or negative excess charge (EXCH: calculation is the same as that in the caption to Fig. 5). The parallel lines show the trends of the ideal substitution $3 R^{2+} \leftrightarrow\left(2 R^{3+}+\square\right)$ at different proportions of vacancies in the $X$ site ( $\left.{ }^{X}\right)$ : I 0, II 0.2, III 0.4, IV 0.6 , and V 0.8 . Symbols indicate tourmaline compositions in which $\square^{X}$ has five ranges of values: circle $0.0-0.2$; dot $0.2-0.4 ;$ cross $0.4-0.6$; triangle $0.6-$ 0.8 ; rhomb $0.8-1.0$. See text for details.

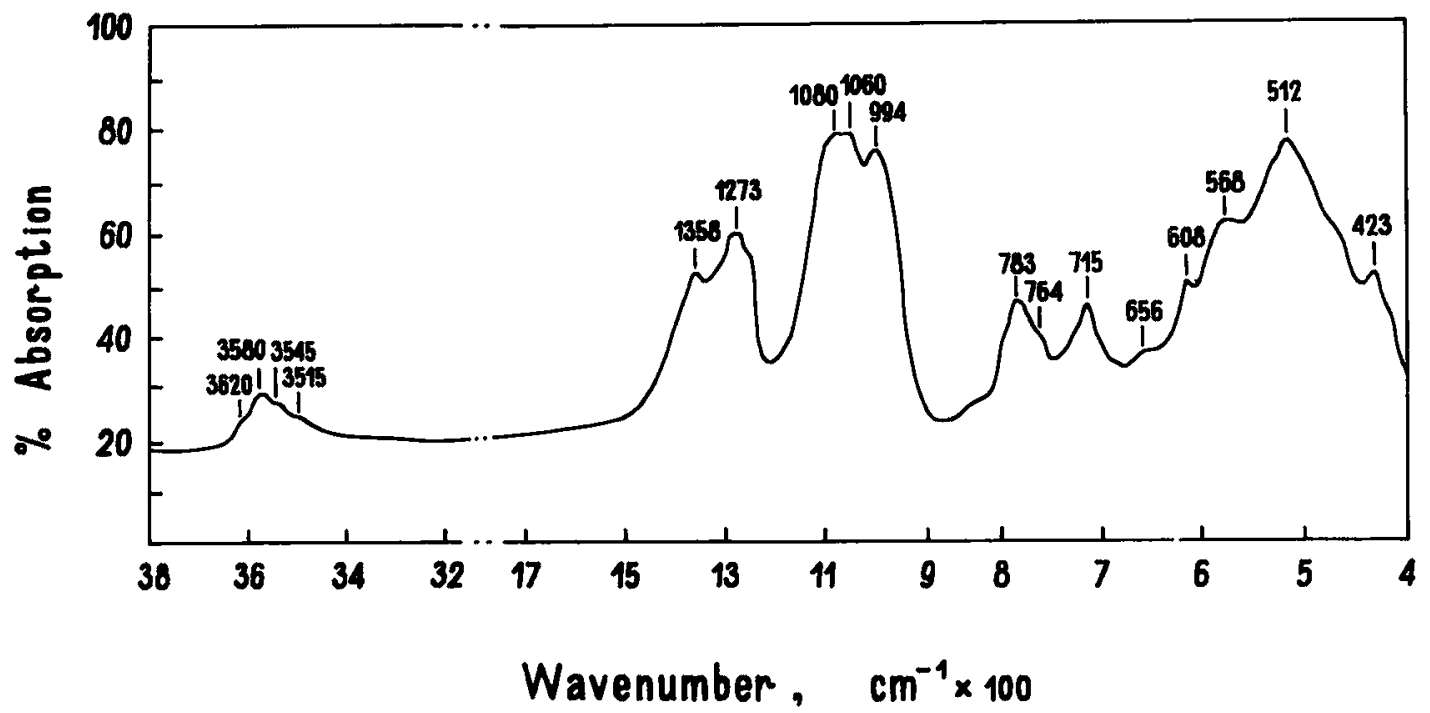

FIG. 7. Infrared absorption spectrum of V-Cr-bearing tourmaline (Primorye, Russia) in the 400 to $3800 \mathrm{~cm}^{-1}$ region. The principal absorption bands are indicated. 


\section{REFERENCES}

AFonin, V.P., PeRflL yeVa, L.A. \& LaVRentyev, Yu.G. (1971): A computer program for quantitative electron probe microanalysis of different chemical compositions. Siberian Geochem. Inst. Year Book 1970, 398-401 (in Russ.).

BADALOV, S.T. (1951): A new variety of tourmaline. Zap. Uzbek. Otd. Vses. Mineral. Obshchest. 2, 84-89 (in Russ.).

BASSET, H. (1956): A vanadiferous variety of tourmaline from Tanganyika. Rec. Geol. Surv. Tanganyika 3, 93-96.

Dolomanova, E.I., Ziborova, T.A., LOSEVA, T.I., Martynova, A.P. \& PaNova, M.A. (1978): Tourmaline from Transbaikalian tin deposits and its typomorphic significance. New Data on Minerals from the USSR 26, 40-69 (in Russ.).

DuNN, P.J. (1977): Chromium in dravite. Mineral. Mag. 41, 408-410.

FOIT, F.F., JR. \& ROSENBERG, P.E. (1977): Coupled substitution in the tourmaline group. Contrib. Mineral. Petrol. 62, 109-127.

\& (1979): The structure of vanadium-bearing tourmaline and its implications regarding tourmaline solidsolutions. Am. Mineral. 64, 788-798.

Gonzalez-Carreno, T., Fernandez, M. \& Sanz, J. (1988): Infrared and electron microprobe analysis of tourmalines. Phys. Chem. Minerals 15, 452-460.

Hammarstrom, J.M. (1989): Mineral chemistry of emeralds and some associated minerals from Pakistan and Afghanistan: an electron microprobe study. In Emeralds of Pakistan: Geology, Gemology and Genesis (A.H. Kazmi \& L.W. Snee, eds.). Geological Survey of Pakistan and Van Nostrand Reinhold Co., New York (125-150).

IMAI, H., LEE, H.K. \& MACHIDA, M. (1980): Vanadium-bearing green mica from the Jangsan quartzite in Janggun mine area, Republic of Korca. Clay Sci. 5, 221-236.

JAN, M.Q., KEMPE, D.R.C. \& SYMES, R.F. (1972): A chromian tourmaline from Swat, West Pakistan. Mineral. Mag. 38, 756-759.

KING, R.W. \& KERRICH, R. (1989): Chromian dravite associated with ultramafic-rock-hosted Archean lode gold deposits, Timmins - Porcupine district, Ontario. Can. Mineral. 27, 419-426.

KrTAEv, I.V. \& LIKrT, F.P. (1971): Determination of general and organic carbon content in rocks by gasometric technique. In Voprosy Litol. i Geokh. Vulkanog - Osadoch. Obraz. Yuga Dalnego Vostoka (E.M. Kireeva \& V.F. Ignatova, eds.). USSR Acad. Sci., Far East Centre, Geol. Inst. Vladivostok, 238-244 (in Russ.).
KOLPACK, R.L. \& BELL, S.A. (1968): Gasometric determination of carbon in sediments by hydroxide absorption. J. Sediment. Petrol. 38, 617-620.

KORNETOVA, V.A. (1981): Tourmaline. In Handbook on Minerals, III/2 (F.V. Chukhrov, ed.). Nauka, Moscow (173-175; in Russ.).

KuzMin, V.I., Dobrovolskaya, N.V. \& SolNTSEVA, L.S. (1979): Tourmaline and its Application for Prospecting. Nedra, Moscow (in Russ.).

MANSKAYA, S.M. \& DROZDOVA, T.V. (1964): Geochemistry of Organic Matter. Nauka, Moscow (in Russ.).

Nakhmanson, M.S. \& ANTOShulsky, A.G. (1985): Powder $\mathrm{X}$-ray pattern methods for computer calculation of cell parameters. Equipment and Technique of X-ray Analysis 33, 27-35 (in Russ.).

NICKEL, E.H. \& GREY, I.E. (1986): A vanadium-rich mineral assemblage associated with the gold telluride ore at Kalgoorlie, Western Australia. In Crystal Chemistry of Minerals (J. Minceva-Stefanova, ed.). Bulgarian Acad. Sci., Sofia, Bulgaria (899-908).

NubeR, B. \& SCHMETZER, K. (1979): Die Gitterposition des $\mathrm{Cr}^{3+}$ im Turmalin: Structurverfeinerung eines $\mathrm{Cr}$-reichen Mg-Al-Turmalins. Neues Jahrb. Mineral. Abh. 137, 184197.

Pan, Yuanming \& Fleet, M.E. (1992): Mineral chemistry and geochemistry of vanadian silicates in the Hemlo gold deposit, Ontario, Canada. Contrib. Mineral. Petrol. 109, 511-525.

Peltola, E., Vuorelannen, Y. \& HäkLI, T.A. (1968): A chromian tourmaline from Outokumpu, Finland. Geol. Soc. Finland, Bull. 40, 35-38.

RUMYANTSEVA, E.V. (1983): Chrome-dravite - a new mineral from Karelia. Zap. Vses. Mineral. Obshchest. 112(2), 222-225 (in Russ.).

MrSHCHENKo, K.S. \& KALINICHEVA, L.I. (1984): Tainiolite and chrome-vanadium micas in metasomatites of Karelia. Zap. Vses. Mineral. Obshchest. 113(1), 68-75 (in Russ.).

Rusanov, A.K. (1978): Principles of Quantitative Spectral Analysis of Ores and Minerals. Nedra, Moscow (in Russ.).

Schmetzer, K., Nuber, B. \& Abraham, K. (1979): Zur Kristallchemie Magnesium-reicher Turmaline. Neues Jahrb. Mineral. Abh. 136, 93-112.

SNETSINGER, K.G. (1966): Barium-vanadium muscovite and vanadium tourmaline from Mariposa County, California. Am. Mineral. 51, 1623-1639.

Received April 4, 1989, revised manuscript accepted July 7 , 1992. 